\title{
Identification and Prioritization of Employee Satisfaction Strategies in Tehran Regional Water Company Using Analytic Hierarchy Process (AHP)
}

\author{
Nasim Bonyadi*, Hormat Asghari, Mojtaba Kiaei
}

\begin{abstract}
Employee satisfaction is one of the main indicators of attitudes assessment in organizations and is one of the factors which can be used to assess the status of an organization. This is important because of the role that this construct plays in improvement of the organization and the workforce. Organizationally, a high level of job satisfaction reflects a highly desirable organizational climate which leads to recruitment and retention of employees and increases efficiency and effectiveness. Accordingly, this study tended to identify and prioritize employee satisfaction strategies in Tehran's Regional Water Company using analytic hierarchy process (AHP). The data was analyzed using AHP method by Expert Choice software. The statistical population included 16 experts in human sciences and in management science working in the Tehran Regional Water Company. Due to the limited number of statistical population, sampling was not used and census method was used; that is, all people in the statistical population participated in the study. Prioritization of the criteria showed that organizational strategies are the most important, followed by organizational policies and organizational achievements. Sub-criteria of these criteria were also prioritized.
\end{abstract}

Keywords: analytic hierarchy process; employee satisfaction; organizational policy; organizational strategies

\section{INTRODUCTION}

In the present era, movement towards specialization of works has become increasingly evident due to complexity of human life. This has led to actions by scholars and intellectuals of various societies in order to solve problems of the modern man. Solving these problems in any society is possible through dynamic, strong and progressive organizations that can take effective steps in dividing social functions into specific goals to meet social needs. Speaking of the organization and working groups formally and informally to meet social needs, management and leadership are the focus of its activities, because the necessary material, human and functional resources will not be used properly until there are professional human resources and qualified effective managers. Among these resources, human resources are the most important factor in survival of organizations. Studying and reviewing the history of industrial development shows that the skilled, committed and highly satisfied human resources have had an undeniable effect in transformation of traditional society into industrial society, so that human resources have been considered as the most important and main factor for development of societies and organizations [1]. Undoubtedly, committed employees can bring future organizational success. By concentrating on commitment, these forces move towards organizational strategic goals and pave the way for organizational excellence. The study of job satisfaction is important from two dimensions: first, the human aspect in which employees deserve to be treated equitably and with respect; second, the behavioral aspect in which attention to job satisfaction can direct employee behavior to influence their function and organizational tasks and lead to positive and negative behaviors [2]. Job satisfaction refers to all feelings of a person about their job. Job satisfaction depends on the nature and expectations of the jobs. Therefore, job satisfaction is the emotional orientation that employees have about their job [3,
4]. Job satisfaction leads to functional outcomes in the organization. Scholars argue that job satisfaction leads to productivity and organizational commitment [5]. In addition to examining the consequences of job satisfaction, recognizing effective factors on job satisfaction also helps managers improve their work and achieve organizational goals, so that mutual benefits of the employees and the organization are provided [6,7]. Accordingly, it is important to study employee satisfaction strategies; given the fact that this has been investigated rarely by scholars in the Tehran Regional Water Company, the resulting gap is explicitly evident. Therefore, this study tends to help fill this research gap. In this research, we have proposed a methodology based on AHP. Furthermore, experts' judgment is used for prioritizing the global weights of employee satisfaction strategies.

\section{LITERATURE REVIEW}

Job satisfaction: job satisfaction is a set of feelings and beliefs that people have about their current occupations. Job satisfaction is one of the important factors in job success, which increases efficiency and individual satisfaction [8].

Organizational strategies: Decision on policies related to organizational goals and changes in those goals, the resources used in them, the characteristics of these resources and their distribution and application, and in a shorter definition in the same sense, the strategy is a complete set of certain policies and goals of an organization [9].

Organizational policy: Policy is the principle that determines the scope of decision-making for managers of an organization or board of directors. Planning and implementation managers in each organization always take into account the scope determined by the policy and make decisions which are consistent with the policy [10].

Organizational achievement: In a brief definition, each organization brings along a set of practices and procedures 
and employees are exposed to these achievements and outcomes [11].

Hojat Panah and Heidarnattaj [12] studied the effective factors on job satisfaction in the administrative workplace. According to overviews carried out in this study, it was concluded that physical conditions in workplaces play a major role in satisfaction, comfort, welfare, effectiveness, or even mental health of people. Therefore, physical environment of the departments should be planned, designed and managed more carefully; otherwise, the physical environment would have a negative effect on health and wellbeing of people and cause occupational anxiety in employees. Zare Mehrjordi [13] studied organizational, occupational and individual effective factors on job satisfaction through a case study on Meybod Industrial Town workers. The results of the hypothesis testing show that women, married people and those with formal employment have higher job satisfaction. Older workers with more dependents and lower monthly household expenses have higher job satisfaction. In other words, workers with more difficult living conditions are more satisfied. Munir and Abdul Rahman [14] determined the dimensions of job satisfaction using factor analysis. The findings showed that many respondents in the survey suffer from dissatisfaction in the workplace. For this reason, remarks and suggestions were proposed to raise the level of employee satisfaction. Ayranci [15] studied factors of job satisfaction among private entrepreneurs through a case study in an industrial town. The results show that business owners can raise productivity in their company by employing motivational factors and providing conditions for employee satisfaction. Ledimo and Martins [16] tended to validate employee satisfaction through a structural equation with model approach. This study validated a model of employee satisfaction using structural equation modeling (SEM). The results of this study showed that the identified variables were effective on employee satisfaction. Neog and Barua [17] studied effective factors on employee job satisfaction through an experimental study in employees of auto service workshops in Assam. The results showed that salary and wages present the most important effective factor on employee job satisfaction. With the exception of salary and wages, it was determined that the effect of supervisor support, healthy working environment, proper balance between work and life, job opportunities and promotion, proper education and development opportunities are also important factors in determining job satisfaction of employees. Hong et al. [18] studied effective factors on job satisfaction among factory workers in Seremban, Malaysia. The results show that the work environment, payment and salaries, and promotion criteria had a significant effect on the level of employee satisfaction, while it was concluded that justice had no effect on employee satisfaction.

\section{MATERIALS AND METHODS}

In terms of objective, this was an applied research and the results can be directly used in Tehran Regional Water
Company. In terms of control of variables and data collection method, this was a descriptive survey. Through archival studies, data was collected from relevant resources, including data collection instruments and literature review. After collecting the necessary data and sampling from the statistical population, the questionnaire was distributed among the statistical sample and its results were analyzed.

\subsection{Population, Sampling and Sample Size}

The statistical population of this study included 16 experts in human sciences and management science in Tehran Regional Water Company. It should be noted that since AHP was used in this study, a limited statistical population was required. Considering the limited number of statistical population, sampling was not used and the census method was used. In other words, the number of samples was equal to the number of people in the statistical population and included 16 experts in human sciences and management working in the Tehran Regional Water Company. One of the necessities of any study is availability of reliable information and the speed and ease of access to it [19].

\subsection{Data Collection Instrument}

The data collection instrument in this study was a Likerttype questionnaire as well as a researcher made questionnaire using AHP. In the Likert-type questionnaire, the effect of criteria and sub-criteria were measured on satisfaction of Tehran Regional Water Company employees. The Likerttype questionnaire consisted of 13 items; items 1 to 3 measured organizational strategies, items 4 to 10 measured policies, and items 11 to 13 measured organizational achievements. In fact, the instrument used was evaluative and it evaluated the criteria and sub-criteria of employee satisfaction for prioritization. This section consisted of four questionnaires which prioritized the strategies and subcriteria. In the first questionnaire, organizational strategies, organizational policies, and organizational achievements were evaluated. In the second questionnaire, priority subcriteria of the organizational strategies (vision and mission, values and leadership) were prioritized. The third questionnaire prioritized sub-criteria of organizational policies (change management, health and security, organizational communications, equity, job diversity, human resources management, and education and development). In the fourth questionnaire, sub-criteria of achievements including working relations, group work and job satisfaction were prioritized.

\subsection{Model of Variables}

The model of the variables studied is shown in Fig. 1. These criteria, which are in fact employee satisfaction strategies, are the most important identified criteria, derived from Ledimo and Martins [16]. 


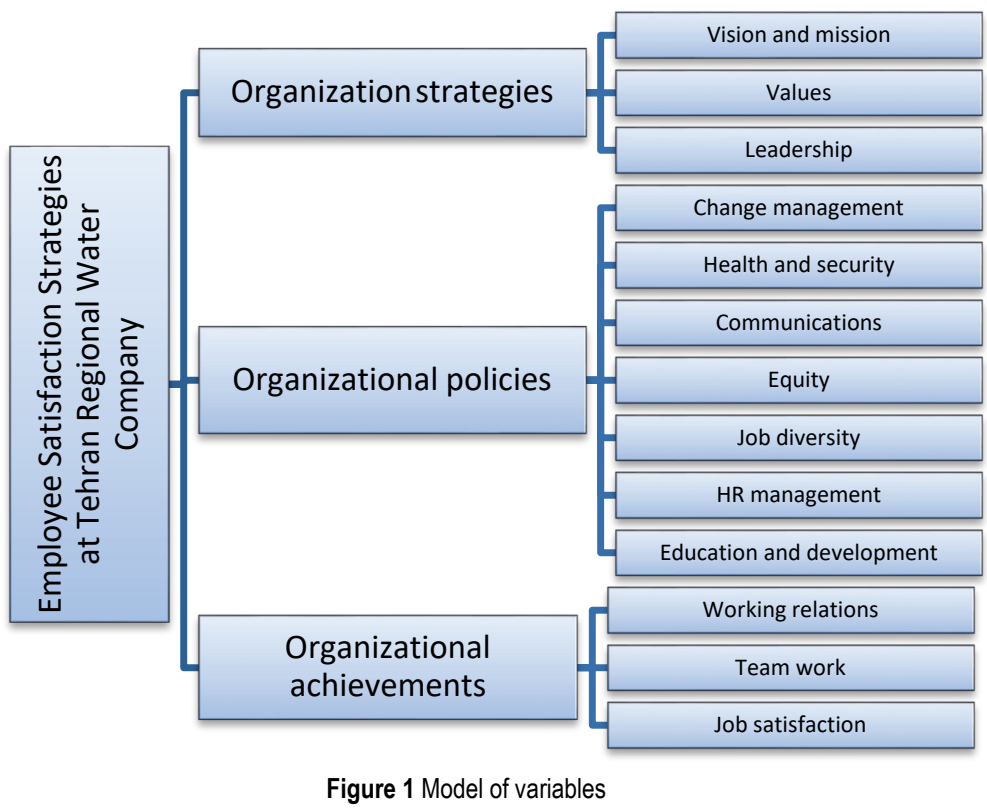

\subsection{Data Analysis}

Analytic hierarchy process (AHP) is one of the most popular multivariate decision-making techniques first developed by Saaty in 1980 [17]. This method can be used when decision-making has multiple choice alternatives and decision criteria. The proposed criteria can be quantitative and qualitative. The choice of criteria is the first part of AHP. Based on the identified criteria, candidates are evaluated. The term alternatives or candidates are used interchangeably. This method is one of the most widely used methods for ranking and determining the importance of factors, which uses a paired comparison of alternatives to prioritize each criterion. AHP has been applied widely for investigating different decision-making problems such as selecting simulation software package [18], information systems outsourcing decisions [19], cloud adoption in healthcare [21], sector risk managements $[21,22]$, and etc.

\section{RESULTS}

\subsection{Demographic Characteristics of Respondents and} Population

Tab. 1 shows demographic characteristics of experts.

Table 1 Demographic characteristics of respondents

Table 1 Demographic characteristics of respondents
\begin{tabular}{|c|c|c|c|}
\hline \multicolumn{2}{|c|}{} & $\%$ & $N, \%$ \\
\hline \multirow{2}{*}{ Gender } & Male & 14 & 88 \\
\cline { 2 - 4 } & Female & 2 & 12 \\
\hline \multirow{3}{*}{ Age } & $<40$ years & 1 & 6 \\
\cline { 2 - 4 } & $40-50$ years & 12 & 75 \\
\cline { 2 - 4 } & $>50$ years & 3 & 19 \\
\hline \multirow{3}{*}{ Education } & Bachelor & 2 & 12 \\
\cline { 2 - 4 } & Master & 11 & 69 \\
\cline { 2 - 4 } & PhD & 3 & 19 \\
\hline \multirow{3}{*}{ Experience } & $5-10$ years & 0 & 0 \\
\cline { 2 - 4 } & $10-20$ years & 4 & 24 \\
\cline { 2 - 4 } & $>20$ years & 12 & 76 \\
\hline
\end{tabular}

\subsection{Inferential Data Analysis}

Factor Analysis of Questions: Before performing any analysis on the collected data and statistical inference, reliability and validity of the measuring instrument must be ensured first. Reliability of the questionnaire was measured by Cronbach's alpha test and the test results indicated that the questionnaires used were reliable and accurate. In order to evaluate the validity based on the fact that the variables consisted of several dimensions (criteria), confirmatory factor analysis was used. In conducting factor analysis, it should be ensured whether existing data can be used for analysis. For this purpose, $K M O$ index and the Bartlett test were used [23]. Based on these two tests, the data are suitable for factor analysis if $K M O>0.6$ and close to one and $\mathrm{Sig}<0.05$ for the Bartlett's test. The outputs of these tests are presented in the following tables.

Table $2 \mathrm{KMO}$ and Bartlett's test for questions of the questionnaire

\begin{tabular}{|c|c|c|}
\hline \multicolumn{2}{|c|}{$K M O$} & 0.662 \\
\hline \multirow{3}{*}{ Bartlett's test } & $\chi^{2}$ & 192.119 \\
\cline { 2 - 3 } & Df & 78 \\
\cline { 2 - 3 } & Sig & 0.000 \\
\hline
\end{tabular}

According to this table, $K M O=0.62(>0.6)$ indicates that the sample number (number of respondents) is sufficient for factor analysis. Moreover, Sig $<0.05$ indicates that the factor analysis is suitable for identifying the structure of the factor model and rejects the assumption that the correlation matrix is known.

\subsection{Prioritization}

The second question stated that how employee satisfaction strategies can be prioritized in Tehran regional water company? To answer this question, AHP was used.

AHP Results for Criteria: Three criteria and a number of sub-criteria were identified to prioritize factors of 
employee satisfaction strategies in Tehran Regional Water Company based on AHP. The matrix of paired comparisons integrated of 16 decision makers is as follows.

Table 3 Matrix of paired comparisons of criteria
\begin{tabular}{|l|c|c|c|}
\hline \multicolumn{1}{|c|}{ Criteria } & Strategies & Policies & Achievements \\
\hline Strategies & 1 & & \\
\hline Policies & & 1 & \\
\hline Achievements & & & 1 \\
\hline
\end{tabular}

By modelling by the Expert Choice software and inserting the matrix of paired comparisons, the weights of criteria and sub-criteria were obtained as shown below. Organizational strategies (relative weight 699) was the most important factor, followed by policy $(0.156)$ and organizational achievements $(0.145)$. Inconsistency rate of paired comparisons was 0.02 ; because $I R<0.10$, comparisons are acceptable.

Table 4 Prioritization of criteria of employee satisfaction strategies

\begin{tabular}{|l|c|c|}
\hline \multicolumn{1}{|c|}{ Criteria } & Weight & Priority \\
\hline Strategies & 0.699 & 1 \\
\hline Policies & 0.156 & 2 \\
\hline Achievements & 0.145 & 3 \\
\hline
\end{tabular}

Relative weight of criteria of organizational strategies: Using the literature and relevant experts, 7 criteria and a number of sub-criteria were identified in order to prioritize factors of organizational strategies based on integration of decision-making methods using AHP. The matrix of paired comparisons integrated of the decision makers are shown in the tables below. The paired comparisons of each criterion with respect to economic factor are presented in Table 5. According to the table, it is indicated that the relationship between all sub-criteria is bilateral.

Table 5 Prioritization of criteria based on organizational strategies

\begin{tabular}{|l|c|c|}
\hline \multicolumn{1}{|c|}{ Criterion } & Weight & Priority \\
\hline Mission and vision & 0.706 & 1 \\
\hline Values & 0.172 & 2 \\
\hline Leadership & 0.123 & 3 \\
\hline
\end{tabular}

Considering the main weight obtained, the most important criterion is mission and vision, followed by values and leadership. Given that the inconsistency rate obtained is 0.01 , which is less than the standard level of 0.1 , the questionnaire was completed with high precision by the respondents.

Relative weight of criteria of organizational policies

Using the literature and relevant experts, seven criteria and a number of sub-criteria were identified in order to prioritize factors of organizational policies based on integration of decision-making methods using AHP. The matrix of paired comparisons integrated of the decision makers are shown in the tables below. The paired comparisons of each criterion with respect to economic factor are presented in Table 6 . According to the table, it is indicated that the relationship between all sub-criteria is bilateral.

Considering the main weight obtained, the most important criterion is education and development, followed by communications, change management, HR management, health and security, job diversity and equity. Given that the inconsistency rate obtained is 0.09 , which is less than the standard level of 0.1 , the questionnaire was completed with high precision by the respondents.

Table 6 Prioritization of criteria based on organizational policies

\begin{tabular}{|l|c|c|}
\hline \multicolumn{1}{|c|}{ Criterion } & Weight & Priority \\
\hline Change management & 0.149 & 3 \\
\hline Health and security & 0.130 & 5 \\
\hline Communications & 0.161 & 2 \\
\hline Equity & 0.110 & 7 \\
\hline Job diversity & 0.130 & 6 \\
\hline HR management & 0.145 & 4 \\
\hline Education and development & 0.175 & 1 \\
\hline
\end{tabular}

Relative weight of criteria of organizational achievements: Using the literature and relevant experts, 7 criteria and a number of sub-criteria were identified in order to prioritize factors of organizational achievements based on integration of decision-making methods using AHP. The matrix of paired comparisons integrated of the decision makers are shown in the tables below. The paired comparisons of each criterion with respect to economic factor are presented in Table 7. According to the table, it is indicated that the relationship between all sub-criteria is bilateral.

Table 7 Prioritization of criteria based on organizational achievements

\begin{tabular}{|l|c|c|}
\hline \multicolumn{1}{|c|}{ Criterion } & Weight & Priority \\
\hline Working relations & 0.623 & 1 \\
\hline Team work & 0.234 & 2 \\
\hline Job satisfaction & 0.143 & 3 \\
\hline
\end{tabular}

Considering the main weight obtained, the most important criterion is working relations, followed by team work and job satisfaction. Given that the inconsistency rate obtained is 0.09 , which is less than the standard level of 0.1 , the questionnaire was completed with high precision by the respondents.

\section{DISCUSSION}

The participants in the study were 16 experts in human sciences and management working in the Tehran Regional Water Company; 14 of them were men and 2 of them were women. One of the participants was aged younger than 40 years, 12 were between 40 and 50 years, and 3 were older than 50 years; $12 \%$ had bachelor's degree, $69 \%$ had MA and $9 \%$ had $\mathrm{PhD}$. After identifying the number of participants, distribution of questions based on central indicators, dispersion and distribution was determined and inferential analysis of data was done. In this section, reliability and validity of the instrument were first measured. The reliability of the questionnaire was measured by Cronbach's alpha test and the results of the test showed that the questionnaires used had the required reliability and accuracy. To assess the validity, the confirmatory factor analysis test was used. For this purpose, the $K M O$ index and the Bartlett test were used. According to this study, $K M O=0.62(>0.6)$ indicates that the number of samples (number of respondents) was sufficient for factor analysis. Moreover, the value of Sig of Bartlett's test was less than 0.05 , which showed that the factor analysis 
is suitable for identifying the structure of the factor model and the assumption that the correlation matrix is known is rejected. Subsequently, ranking of variables was performed using AHP. At the beginning of this study, criteria and then the sub-criteria were ranked. Tab. 8 summarizes the prioritization of criteria and their sub-criteria from top to bottom, respectively:

Table 8 Prioritization of criteria and sub-criteria

\begin{tabular}{|c|c|c|c|}
\hline $\begin{array}{c}\text { Prioritization } \\
\text { of criteria }\end{array}$ & Strategies & Policies & Achievements \\
\hline Strategies & $\begin{array}{l}\text { Vision and } \\
\text { mission }\end{array}$ & $\begin{array}{c}\text { Education and } \\
\text { development }\end{array}$ & $\begin{array}{l}\text { Working } \\
\text { relations }\end{array}$ \\
\hline Policies & Values & Communications & Teamwork \\
\hline \multirow[t]{5}{*}{ Achievements } & Leadership & $\begin{array}{c}\text { Change } \\
\text { management }\end{array}$ & $\begin{array}{c}\text { Job } \\
\text { satisfaction }\end{array}$ \\
\hline & & HR management & \\
\hline & & $\begin{array}{c}\text { Health and } \\
\text { security }\end{array}$ & \\
\hline & & Job diversity & \\
\hline & & Equity & \\
\hline
\end{tabular}

Neog and Barua [24] have shown that the level of job satisfaction is moderate, and it is imperative for managers to increase the level of job satisfaction of employees. One of the differences of this study with our study is the difference in statistical population and spatial scope. Moreover, the difference in effective factors and strategies is also significant. With these interpretations, it can be claimed that this study is almost consistent with our study. Hong et al. [25] found that the workplace, payment and salaries, and promotion criteria had a significant effect on the level of employee satisfaction, while the present study concluded that justice has no effect on employee satisfaction; therefore, our study is almost consistent with this study. Zadeh Tabari and Fallah [26] evaluated the effective factors on job satisfaction using fuzzy AHP through a case study on Iran-Zamin Bank. The results of both studies indicate the effect of the factors and strategies on employee satisfaction. In general, our study can be consistent with this study.

\section{CONCLUSION}

In this paper, for the first time, a methodology for identifying and prioritizing the employee satisfaction strategies in water sector based on AHP is proposed. Various criteria were considered such as Organizational strategies, Organizational policy, and Organizational achievement. These criteria were then structured hierarchically into different sub-criteria. Finally, a case study in water industry was conducted to apply this methodology in identifying and prioritizing as a case by using judgments of 16 experts who had worked in the human resource field and then the outcomes were represented. Ranking were as follows: organizational strategies in criteria, vision and mission in organizational strategies, education and development in organizational policies, working relations in organizational achievements. For the extension of this work, multi-criteria decision making methods or fuzzy methods for evaluation employee satisfaction strategies can be used. Also, other factors or strategies may be applied.

\section{REFERENCES}

[1] Nourani, A., Naderi, A., \& Ebrahimi Kharkeshi, I. (2015). The role of job satisfaction in fostering efficient human resources. Sustainable development in educational sciences and psychology $3^{\text {rd }}$ national conference. Tehran: Center of Sustainable Development Solutions.

[2] Golden, T. D. \& Veiga, J. F. (2008). The impact of superiorsubordinate relationships on the commitment, job satisfaction, and performance of virtual workers. The Leadership Quarterly, 19(1), 77-88. https://doi.org/10.1016/j.leaqua.2007.12.009

[3] Liu, D., Gong, Y., Zhou, J., \& Huang, J. C. (2017). Human resource systems, employee creativity, and firm innovation: The moderating role of firm ownership. Academy of Management Journal, 60(3), 1164-1188. https://doi.org/10.5465/amj.2015.0230

[4] Huang, Y. H., Lee, J., McFadden, A. C., Murphy, L. A., Robertson, M. M., Cheung, J. H., and Zohar, D. (2016). Beyond safety outcomes: An investigation of the impact of safety climate on job satisfaction, employee engagement and turnover using social exchange theory as the theoretical framework. Applied ergonomics, 55, 248-257. https://doi.org/10.1016/j.apergo.2015.10.007

[5] Macintosh, G. \& Krush, M. (2014). Examining the link between salesperson networking behaviors, job satisfaction, and organizational commitment: Does gender matter? Journal of Business Research, 67(12), 2628-2635. https://doi.org/10.1016/j.jbusres.2014.03.022

[6] Verbeke, W., Dietz, B., \& Verwaal, E. (2011). Drivers of sales performance: a contemporary meta-analysis. Have salespeople become knowledge brokers? Journal of the Academy of Marketing Science, 39(3), 407-428. https://doi.org/10.1007/s11747-010-0211-8

[7] Wang, W., Newman, D. A., \& Dipboye, R. L. (2016). Social network contagion in the job satisfaction-intention-turnover model. In Academy of Management Proceedings (Vol. 2016, No. 1, p. 17930). Briarcliff Manor, NY 10510: Academy of Management. https://doi.org/10.5465/ambpp.2016.82

[8] Yari, A. (2010). The relationship between job satisfaction and job burnout among employees. MA report, payam nour university of Tehran.

[9] Kerlinová, A. \& Tomášková, E. (2014). Approach to strategy at public administration organizations in the Czech Republic. Procedia-Social and Behavioral Sciences, 156, 8892. https://doi.org/10.1016/j.sbspro.2014.11.125

[10] Babai, M., Yazdani, S., \& Namvar, M. (2015). Measuring the effect of organizaitonal structure on policy making in a public organization. Business: opportunities and challenges international conference. Rasht: Vocational University of Mirza Kouchak Khan.

[11] Kanten, P., Kanten, S., \& Gurlek, M. (2015). The effects of organizational structures and learning organization on job embeddedness and individual adaptive performance. Procedia Economics and Finance, 23, 1358-1366. https://doi.org/10.1016/S2212-5671(15)00523-7

[12] Hojat Panah, H. \& Heidarnattaj, V. (2015). Effective factors on job satisfaction in the administrative workplace. Architecture and urban planning engineering international conference. Tehran: Permanent Secretariat of the Conference.

[13] Zare Mehrjordi, R. (2015). Effective organizational, occupational and individual factors on job satisfaction; a case study: workers of the Meybod industrial town. Psychology and social sciences $5^{\text {th }}$ international conference. Tehran: Mehr Eshragh Hamayeshgaran. 
[14] Munir, R. I. S. \& Rahman, R. A. (2016). Determining dimensions of job satisfaction using factor analysis. Procedia Economics and Finance, 37, 488-496. https://doi.org/10.1016/S2212-5671(16)30156-3

[15] Ayranc1, A. E. \& Ayranc1, E. (2015). A research on job satisfaction factors of private entrepreneurs: The case of Beylikduzu organized industrial zone. Procedia-Social and Behavioral Sciences, 195, 268-277. https://doi.org/10.1016/j.sbspro.2015.06.156

[16] Ledimo, O. \& Martins, N. (2015). Validation of an employee satisfaction model: A structural equation model approach. Journal of Governance and Regulation, 4(1), 78-87. https://doi.org/10.22495/jgr_v4_i4_p8

[17] Saaty, T. L. (1980). The analytic hierarchy process. McGraw Hill, New York. https://doi.org/10.21236/ADA214804

[18] Azadeh, A., Shirkouhi, S. N., \& Rezaie, K. (2010). A robust decision-making methodology for evaluation and selection of simulation software package. The International Journal of Advanced Manufacturing Technology, 47(1-4), 381-393. https://doi.org/10.1007/s00170-009-2205-6

[19] Nazari-Shirkouhi, S., Miri-Nargesi, S., \& Ansarinejad, A. (2017). A fuzzy decision making methodology based on fuzzy AHP and fuzzy TOPSIS with a case study for information systems outsourcing decisions. Journal of Intelligent \& Fuzzy Systems, 32(6), 3921-3943. https://doi.org/10.3233/JIFS-12495

[20] Sharma, M. \& Sehrawat, R. (2020). A hybrid multi-criteria decision-making method for cloud adoption: Evidence from the healthcare sector. Technology in Society, 101258. https://doi.org/10.1016/j.techsoc.2020.101258

[21] Samadi, H., Nazari-Shirkouhi, S., \& Keramati, A. (2014). Identifying and analyzing risks and responses for risk management in information technology outsourcing projects under fuzzy environment. International Journal of Information Technology \& Decision Making, 13(06), 1283-1323. https://doi.org/10.1142/S021962201450076X

[22] Keramati, A., Nazari-Shirkouhi, S., Moshki, H., AfshariMofrad, M., \& Maleki-Berneti, E. (2013). A novel methodology for evaluating the risk of CRM projects in fuzzy environment. Neural Computing and Applications, 23(1), 2953. https://doi.org/10.1007/s00521-012-1216-7

[23] Hair, J. F., Black, W. C., Babin, B. J., Anderson, R. E., \&Tatham, R. L. (2006). Multivariate Data Analysis. $6^{\text {th }}$ Edition, Prentice Hall, New Jersey.

[24] Neog, B. B. \& Barua, M. (2014). Factors influencing employee's job satisfaction: An empirical study among employees of automobile service workshops in Assam. The SIJ Transactions on Industrial, Financial \& Business Management (IFBM), 2(7), 305-316.

[25] Hong, L. C., Hamid, N. I. N. A., \& Salleh, N. M. (2013). A study on the factors affecting job satisfaction amongst employees of a factory in Seremban, Malaysia. Business Management Dynamics, 3(1), 26.

[26] Zadeh Tabari, N. \& Fallah, M. (2015). Evaluation of effective factors on job satisfaction by using fuzzy AHP. Management sciences research $2^{\text {nd }}$ national conference. Tehran: Bouali Research Group.
Authors' contacts:

Nasim Bonyadi

(Corresponding author)

Department of Governmental Management,

Faculty of Management and Economics,

Science and Research Branch, Islamic Azad University,

Tehran, Iran

nasim.bonyadi@iran.ir

\section{Hormat Asghari}

Department of Governmental Management,

Faculty of Management and Economics,

Science and Research Branch, Islamic Azad University, Tehran, Iran

\section{Mojtaba Kiaei}

Department of Governmental Management, Faculty of Management and Economics,

Science and Research Branch, Islamic Azad University,

Tehran, Iran 